\title{
SUSTAV eSPIS U FUNKCIJI EFIKASNOG DJELOVANJA UPRAVNIH I SUDSKIH TIJELA
}

\author{
Prof. dr. sc. Boris Ljubanović* \\ Izv. prof. dr. sc. Bosiljka Britvić Vetma**
}

\author{
UDK: 35.077.2/.3:003/.4(497.5) \\ https://doi.org/10.30925/zpfsr.41.1.14 \\ Ur.: 20. siječnja 2020. \\ Pr.: 14. travnja 2020. \\ Pregledni rad
}

\begin{abstract}
Sažetak
Autori iznose stajališta o potrebi za učinkovitim djelovanjem upravnih $i$ sudskih tijela s posebnim osvrtom na sudačku neovisnost $u$ rješavanju predmeta $i$ suđenje u razumnom roku. Analiziraju sustav eSpis $i$ njegov učinak na brže $i$ efikasnije rješavanje predmeta.
\end{abstract}

Ključne riječi: upravna tijela; sudska tijela; sudačka neovisnost; razumni rok; sustav eSpis.

\section{UVOD}

Republika Hrvatska u svojim reformskim nastojanjima kontinuirano teži učinkovitijem rješavanju predmeta o pravima, obvezama i pravnim interesima stranaka i u upravnim i u sudskim postupcima. Za zaštitu prava stranke u upravnim predmetima važno je stajalište izraženo u odluci Ustavnog suda Republike Hrvatske. ${ }^{1}$ U predmetnoj se odluci navodi: „Pravila i sredstva dokazivanja čine dio cjeline postupovnih pravila upravnog postupka, sadržanih u Zakonu o općem upravnom postupku i kao takva neodvojiva su sastavnica postupovnih jamstava pravičnog suđenja, zaštićenih Ustavom Republike Hrvatske. Ustavni sud štiti ustavno jamstvo pravičnog suđenja (odlučivanja) ispitujući eventualno postojanje postupovnih povreda u postupcima pred sudovima i drugim državnim tijelima, odnosno tijelima koje imaju javne ovlasti. Pružajući tu zaštitu, Ustavni sud sagledava cjelokupni postupak kao jedinstvenu cjelinu te ocjenjuje je li on bio vođen na način koji podnositelju osigurava pravično suđenje (odlučivanje), odnosno je li tijekom postupka počinjena povreda takvog značenja da postupak kao cjelinu čini nepravičnim za podnositelja. Sagledavajući konkretan slučaj s toga stajališta, Ustavni sud primjećuje da je postupanje nadležnih upravnih

* Dr. sc. Boris Ljubanović, redoviti profesor, Pravni fakultet Sveučilišta Josipa Jurja Strossmayera u Osijeku; ljboris@pravos.hr.

** Dr. sc. Bosiljka Britvić Vetma, izvanredna profesorica, Pravni fakultet Sveučilišta u Splitu; bosiljka.britvic@pravst.hr.

1 Više o tome: Bosiljka Britvić Vetma, „Utjecaj konvencijskog prava i prava Europske unije na zaštitu prava stranke u upravnom sporu“, Zbornik Pravnog fakulteta Sveučilišta u Rijeci 37, br. 1 (2016.): 291-315. 
tijela i Upravnog suda utvrđeno u konkretnom slučaju (neosnovano ograničenje dokaznih sredstava, odnosno mogućnosti utvrđivanja relevantnih činjenica u skladu $\mathrm{s}$ načelom materijalne istine, uz bitne nedostatke u obrazlaganju zauzetih stajališta), dovelo do povrede podnositeljeva ustavnog prava na pravično suđenje (odlučivanje) $s$ aspekta općih jamstava sadržanih u članku 29. stavak 1. Ustava, koja jamstva moraju biti poštovana i u postupku sudske kontrole zakonitosti pojedinačnih akata uprave iz članka 19. stavka 2. Ustava.“²

Stoga možemo bez ikakve dvojbe istaknuti da je pravo na rješavanje (suđenje) u razumnom roku jedno od temeljnih prava koje teži učinkovitijem djelovanju upravnih i sudskih tijela. Pravo na rješavanje predmeta u razumnom roku objašnjava se shvaćanjem da je „zakašnjela pravda uskraćena pravda“, a „prebrzo suđenje maćeha pravdi“". Pripada svakom sudioniku sudskog i upravnog postupka u kojem se odlučuje o njegovu pravu ili obvezi ili o pravnom interesu. Prema judikaturi Europskog suda za ljudska prava, razumni je rok vrijeme u kojem treba meritorno okončati postupak, a određuje se prema sljedećim kriterijima: a) složenost pravnih i/ili činjeničnih pitanja konkretnoga slučaja; b) ponašanje podnositelja zahtjeva tijekom postupka, tj. je li on svojim ponašanjem (tzv. procesne sabotaže) pridonio predugom trajanju postupka; c) važnost predmeta spora za podnositelja zahtjeva te d) postupanje suda pred kojim se vodi postupak, tj. je li sud postupao s dužnom revnošću i je li vrijeme neaktivnosti bilo neopravdano i prekomjerno. ${ }^{3}$

Zakon o sudovima iz $2013 .{ }^{4}$ u naš pravni poredak uvodi dva pravna sredstva za zaštitu prava na suđenje u razumnom roku: zahtjev za zaštitu prava na suđenje u razumnom roku i zahtjev za isplatu primjerene naknade zbog povrede prava na suđenje u razumnom roku, pobliže normirano u čl. 63. do 70 .

U upravnim postupcima, međutim ne možemo koristiti ta pravna sredstva, već je jedina predviđena mogućnost zaštita protiv šutnje uprave, $\mathrm{tj}$. žalba zbog nedonošenja rješenja u propisanom roku, odnosno pokretanje upravnog spora (čl. 101. st. 3. Zakona o općem upravnom postupku $)^{5}$ i mogućnost podnošenja ustavne tužbe.

Europski sud za ljudska prava u presudi Počuča protiv Hrvatske iz 2006. ${ }^{6}$ utvrdio je da ustavna tužba nije učinkovito pravno sredstvo u odnosu na duljinu upravnog postupka i upravnog spora zajedno, jer se u ustavnosudskom postupku ne razmatra duljina upravnog postupka, dakle ne razmatraju se svi stadiji postupka, odnosno njegovo ukupno trajanje. Nakon toga, Ustavni je sud RH ocijenio da sredstva pravne zaštite protiv šutnje uprave vrlo često nisu djelotvorna za ubrzanje upravnih postupaka, na što pokazuje upravna praksa u Republici Hrvatskoj. Stoga je ranije pravno stajalište

2 Vidi odluka Ustavnog suda Republike Hrvatske broj: U-III-3937/2001. od 14. prosinca 2011., U-III-2009. od 3. studenog 2001.

3 Više o razumnom roku: Marko Šikić, „Pravo na suđenje u razumnom roku u postupcima pred Upravnim sudom Republike Hrvatske“, Zbornik Pravnog fakulteta Sveučilišta u Rijeci 30, br. 1 (2009.): 333-372; Dario Đerđa i Marko Šikić, Komentar Zakona o upravnim sporovima (Zagreb: Novi informator, 2010.); Frano Staničić i Bosiljka Britvić Vetma, Komentar Zakona o upravnim sporovima (Zagreb: Narodne novine, 2017.).

4 Zakon o sudovima, Narodne novine, br. 28/13., 33/15., 82/15., 82/16., 67/18., 126/19.

5 Zakon o općem upravnom postupku, Narodne novine, br. 47/09.

6 Presuda Рос̌uča protiv Hrvatske od 29. lipnja 2006., br. 22457/02. 
Ustavnog suda o tom pitanju promijenjeno. ${ }^{7}$ U novom pravnom stajalištu Ustavni je sud istaknuo da se i neaktivnošću, odnosno neučinkovitošću tijela državne uprave, drugih državnih tijela i pravnih osoba s javnim ovlastima, kad u upravnim stvarima odlučuju o pravima, obvezama ili pravnim interesima stranaka u upravnom postupku, promatranom zajedno s trajanjem započetog upravnog spora, može doći do povrede čl. 29. st. 1. Ustava RH i čl. 6. st. 1. Europske konvencije za zaštitu ljudskih prava i temeljnih sloboda (dalje u tekstu: EKLJP), u dijelu koji se odnosi na razumnu duljinu odlučivanja o pravima i obvezama stranaka. Trajanje upravnog spora pred Upravnim sudom RH, naime, ne pokazuje stvarno trajanje „spornog“ razdoblja odlučivanja o konkretnoj upravnoj stvari. ${ }^{8}$

Iznesen je dobar primjer usklađivanja prakse Ustavnog suda RH sa stajalištima Europskog suda za ljudska prava vezano za zaštitu prava na suđenje u razumnom roku u upravnim stvarima. ${ }^{9}$

Nužno je napomenuti da nerazumno trajanje postupaka u kojima se odlučuje o nečijem pravu ili obvezi ne dovodi samo do povrede prava na pošteno suđenje, već može imati za posljedicu i povredu nekoga drugog (materijalnog) ljudskog prava. Takav se zaključak može izvesti iz onih presuda Europskog suda za ljudska prava u kojima je zbog nerazumne duljine trajanja domaćih postupaka utvrđena supstantivna povreda EKLJP, kao primjerice povreda prava na poštovanje privatnog života $\mathrm{u}$ presudi Mikulić protiv Hrvatske iz 2001. ili povreda prava na dom u presudi Cvijetić protiv Hrvatske iz 2004. i presudi Pibernik protiv Hrvatske iz 2004. ili povreda prava vlasništva u presudi Lukavica protiv Hrvatske iz 2007. ${ }^{10}$

\section{SUDAČKA NEOVISNOST}

Prema suvremenom shvaćanju, sudačka neovisnost znači da suci sude samo prema svojem pravnom znanju i vezani su samo na ustavna, zakonska i druga važeća pravna pravila, te su slobodni od izvanjskog utjecaja (izvršne vlasti, političkih stranaka i sl.). To je, tzv. suštinska ili supstancijalna sudačka (sudska) neovisnost. Drugi je aspekt sudačke neovisnosti, tzv. osobna sudačka neovisnost koja, s jedne strane, znači da suci imaju siguran i stalan osobni položaj u obavljanju službe (status), a s druge da će pravnim subjektima, čije predmete suci rješavaju, suditi nepristrani suci, odnosno da će od suđenja biti izuzeti suci kod kojih objektivni ili subjektivni razlozi izazivaju sumnju u nepristranost.

Suđenje je, povijesno, djelatnost koja je, kao i drugi oblici vlasti, pripadala

7 Odluka Ustavnog suda RH od 20. lipnja 2007. br: U-IIIA-4882/2005.

8 Novije odluke suglasno s navedenom su, primjerice odluka Ustavnog suda RH od 11. ožujka 2009. br. U-IIIVs-664/2007 i odluka od 20. travnja 2009. br. U-IIIVs-4242/2007.

9 O utjecaju presuda Europskog suda za ljudska prava na odluke Ustavnog suda RH, v.: Željko Potočnjak, „Pravo na sud, pristup sudu i suđenje u razumnom roku u slučaju intervencije zakonodavca u sudske postupke u tijeku“, Zbornik Pravnog fakulteta Sveučilišta u Rijeci br. 2 (2004.): 823-853.

10 Presuda Mikulić protiv Hrvatske od 20. prosinca 2001. br. 52634/99, presuda Cvijetić protiv Hrvatske od 26. veljače 2004. br. 71549/01, presuda Pobernik protiv Hrvatske od 4. ožujka 2004. br. 75139/01 te presuda Lukavica protiv Hrvatske od 5. srpnja 2007. br. 39810/04. 
vladaru. On je tu djelatnost mogao obavljati neposredno (lat. iudex ordinarius) u svom sjedištu ili posredno putem delegiranih sudaca (lat. iudex delegatus). Potonji su bili potpuno podređeni vladaru koji ih je mogao u svakom trenutku ukloniti i sam riješiti slučaj ili rješavanje prenijeti na neko drugo ad hoc formirano tijelo. ${ }^{11}$

Procesi izdvajanja sudstva iz državne uprave trajali su dugo, a završeni su tek pobjedom ideja građanskoga liberalizma i građanske revolucije. ${ }^{12}$ Među tim je idejama ona prema kojoj suđenje valja povjeriti posebnoj grani državne vlasti - sudbenoj vlasti. S tim da se toj vlasti normativnim pravilima zajamči ustrojstvena i funkcionalna samostalnost i nedodirljivost. Konačni rezultat razvoja o kojem je riječ je engleski, tzv. model „sudaca po profesiji“ i kontinentalni, tzv. model „suca službenika“. Spomenuti se modeli bitno razlikuju. Prema engleskom modelu, niža je sudbenost povjerena, uglavnom, sucima laicima u pravu (engl. lower judges), dakle osobama koje nemaju pravničko obrazovanje. Suci viših sudova izabiru se iz redova uglednih odvjetnika s dugogodišnjim iskustvom. Suci i odvjetnici imaju isto zvanje s visokim društvenim ugledom; oni govore istim jezikom..$^{13}$ Dobiveno sudačko mjesto je stalno, tako da u pravilu nema napredovanja u sudačkoj službi. Prema kontinentalnom modelu jasna je podjela između odvjetništva i magistrature. Suci svoju karijeru započinju na nižim sudovima i očekuju napredovanje, tj. promaknuće na više sudove. Bitno je napomenuti da suci u Engleskoj uživaju iznimno visok stupanj neovisnosti, vanjske (prema izvršnoj vlasti i zakonodavcu) i unutrašnje (prema višim sudovima). Pritom se ističe da je u toj zemlji neovisnost sudaca više kulturna nego institucionalna činjenica. Zakonske norme kojima je uređena sudačka neovisnost tek su vidljiv dio ledenoga brijega čiji se korijeni nalaze u samoj ideji veza između dviju profesija (engl. Bench i Bar). ${ }^{14}$

Nužno je naglasiti da je pravo na neovisnog i nepristranog suca (sud) postalo i temeljno ljudsko pravo koje jamče i međunarodna pravila. ${ }^{15}$

11 V. o tome Mihajlo Dika, ,O razvitku instituta sudske (sudačke) nezavisnosti u zapadnoeuropskom civilizacijskom krugu“, Zbornik Pravnog fakulteta u Zagrebu suppl. br. 4 (1992.): 511 i dalje.

12 Pitanje neovisnosti sudaca od vladara prvi je put došlo do snažnog izražaja u borbama engleskoga Parlamenta i pojedinih uglednih kraljevskih sudaca s vladarima iz dinastije Stuart u 17. stoljeću. Riješeno je djelomično Aktom o nasljeđu (engl. Act of Settlement) iz 1701., kojim je uvedena stalnost sudačke službe (kralj više nije mogao ukloniti suca, osim zbog lošeg vladanja na temelju adrese oba doma Parlamenta kralju, ali je nasljednik mogao opozvati postavljanje) te konačno 1760., tijekom vladavine Georga III., kada je stalnost službe zajamčena i nakon smrti kralja. Poznato je da je nakon Francuske revolucije 1789. sudbena vlast odijeljena od zakonodavne i izvršne, ali ne zbog ograničenja i nadziranja triju vlasti, nego usklađenosti izvršne i sudbene vlasti sa zakonodavnom, koja prema shvaćanju revolucionara ima dominantnu ulogu jer izražava narodni suverenitet. Usp. Dika „O razvitku instituta sudske (sudačke) nezavisnosti u zapadnoeuropskom civilizacijskom krugu“ Zbornik Pravnog fakulteta u Zagrebu suppl br. 4 (1992): 518, 526-527; Davor Krapac, Kazneno procesno pravo. Prva knjiga: Institucije (Zagreb: Narodne novine, 2012.): 136-137.

13 V. o tome Nicola Picardi, Rapport General sur l'independance et la Responsabilite des Juges et des Avocats; Congres de l'Association Internationale du Droit Procedural, Comibra - Lisbon 1991 (General Reports): 38 i dalje.

14 Usp. Shimon Shetreet, Judges on Trial: A Study of the Appointment and Accountability of the English Judiciari. (Amsterdam: North-Holland Pub., 1976), 105 i Picardi, Rapport: 48.

15 V. čl. 14. st. 1. Međunarodnog pakta o građanskim i političkim pravima i čl. 6. st. 1. Konvencije 


\section{RAZVOJ SUSTAVA ESPIS}

Projekt razvijanja i provedbe sustava eSpis (prethodnog naziva ICMS) započeo je još 2001. pri Ministarstvu pravosuđa. Cilj mu je bio da se sustav eSpis (elektronički spis) uvede na sudove. Prvi sud na koji je uveden bio je Općinski sud u Puli 2007. (tzv. ,pilot sud“).

Slijedi daljnji razvoj sustava i to u sklopu PHARE programa 2006. godine, u cilju da se od 2009. do zaključno 2010. eSpis uvede na 60 sudova, što je predstavljalo prvu fazu uvođenja sustava e-Spisa na sudove.

Novi Sudski poslovnik ${ }^{16}$ počeo se je primjenjivati od 31. prosinca 2009., kojim je propisana obvezatna upotreba eSpisa. Time su svi sudovi bili obvezatni u svom unutarnjem poslovanju raditi u sustavu eSpis, odnosno primjenjivati sustav eSpis. Navedeno je značilo da je bilo potrebno pristupiti i daljnjim radnjama i analizama sustava eSpis, a sve radi potpune prilagodbe sudova za rad u njemu, odnosno što je više moguće za rad s elektroničkim spisom.

U tom kontekstu konkretno se pristupilo prilagodbi sustava na način da su se usklađivale funkcionalnosti s pojedinim procesnim zakonima, uzimajući u obzir pojedine vrste sporova (npr. parnični postupak, kazneni postupak, ovršni postupak) i pojedine funkcionalnosti, koje je bilo nužno uvesti cijeneći i posebne odredbe materijalnog propisa koji je definirao određene posebnosti za pojedini postupak (parnični ili kazneni), a koje funkcionalnosti, primjerice u prvim etapama rada $\mathrm{u}$ sustavu eSpis nisu bile definirane.

Kao jedan od ciljeva uvođenja sustava eSpis na sudove bilo je ne samo brže, bolje i modernije pravosuđe, odnosno ubrzanje rada sudova, već i omogućavanje razmjene podataka s drugim informacijskim sustavima, odnosno razmjena podataka između sudova i drugih državnih institucija, kao i razmjena podataka između sudova te sudova i državnih odvjetništava, odnosno Hrvatske odvjetničke komore (npr. pristup evidenciji o osobnim identifikacijskim brojevima, pristup kaznenoj evidenciji, sudski registar, e-oglasne ploče sudova). Uvođenje sustava eSpis na sudove omogućilo je i da se statistički i analitički podatci svih sudova pohranjuju i obrađuju na jednom mjestu (središnje mjesto) u Ministarstvu pravosuđa Republike Hrvatske, da se obrađuju jednako te da se upravljačka izvješća jednako primjenjuju na svim sudovima.

Navedeno je značilo da je već pri uvođenju sustava eSpis na sudove u prvoj etapi omogućeno praćenje rada na svim predmetima kroz upisnik radnji, praćenje kretanja spisa na sudu i izvan suda, praćenje troškova pristojbi i troškova vještačenja, praćenje stečajnih postupaka, upotreba barkod tehnologije i upotreba predložaka standardiziranih odluka i dopisa i automatizacija standardiziranih internih naredbi sudova te omogućavanje sinergije sustava eSpis i sustava SupraNova, odnosno cjelovitoga sustava sudske prakse.

Posebno je važna značajka sustava eSpis automatska i nasumična dodjela predmeta. Ta je funkcionalnost iznimno važna jer je europski standard u osiguravanju nepristranosti i neovisnosti rada sudova, odnosno suđenja. Navedeno dovodi do 
potpune transparentnosti i objektivnosti pri dodjeli predmeta u rad sucima, pritom uvažavajući i funkcionalnost težinskih čimbenika, odnosno vrednovanja svake vrste predmeta koji se dodjeljuje konkretnom sucu.

Tijekom 2012. i 2013. godine započela je druga etapa uvođenja sustava eSpis na sudove (IPA projekt 2009). Tako je eSpis uveden na tada preostala 33 općinska suda, a tijekom 2015. donesen je i Pravilnik o radu u sustavu $e$ Spis $^{17}$ koji detaljno i podrobno opisuje pravila postupanja, odnosno rad u sustavu eSpis. Pravilnik je mijenjan i dopunjavan sukladno s tehnološkim unaprjeđenjima i modernizaciji sustava eSpis. ${ }^{18}$ Zaključno, 3. rujna 2018. eSpis je uveden i na Vrhovni sud Republike Hrvatske iz čega nesporno proizlazi njegova važnost u funkciji učinkovitoga djelovanja sudova.

\section{PRIMJENA SUSTAVA ESPIS}

U odnosu na trenutačno činjenično stanje sustava eSpis (primjenjuje se na 49 sudova), nužno je uzeti u obzir i daljnju racionalizaciju pravosudne mreže te spajanje sudova, odnosno eSpis je danas u primjeni na županijskim i općinskim sudovima, Visokom trgovačkom sudu i trgovačkim sudovima te kako je navedeno i na Vrhovnom sudu Republike Hrvatske. Korisnici sustava eSpis su suci, sudski službenici, kao i sudovi te Ministarstvo pravosuđa. Približno je oko 8.000.000 sudskih predmeta u sustavu, dok se mjesečno osniva oko 50.000 novih predmeta, a dnevno se događaju promjene na oko 73.000 predmeta. $^{19}$

Iz navedenog proizlazi kako je svrha i cilj uvođenja sustava eSpis, o čemu su autori već govorili, unaprjeđenje postojećih te uvođenje novih funkcionalnosti za sudove, daljnje povezivanje eSpisa s drugim informacijskim sustavima, nadogradnja postojećih „usluga“ za javnost te prijenos eSpis sustava na novu infrastrukturu, kao i njegova tehnološka modernizacija, a sve u cilju daljnje modernizacije sudova $i$ pravosuđa, ostvarivanja maksimalne transparentnosti kao i povećanja učinkovitosti rada sudova te bolje iskoristivosti kadrovskih i organizacijskih potencijala na sudovima, s vjerojatno konačnim ciljem uvođenja u potpunosti elektroničkog spisa.

Sve je navedeno nužno uzeti u obzir i u analizi u kojoj mjeri i na koji način eSpis može biti u funkciji učinkovitog djelovanja upravnih i sudskih tijela. Pritom se mora uzeti u obzir kako se kao jedna od aktivnosti Ministarstva pravosuđa u 2020. godini predviđa uvođenje eSpisa na upravne sudove i Visoki upravni sud. Dakle eSpis sustav do danas nije uveden na upravne sudove i Visoki upravni sud Republike Hrvatske.

U odnosu na potonje, potrebno je navesti kako je prije uvođenja sustava eSpis na upravne sudove i Visoki upravni sud Republike Hrvatske, potrebno prilagoditi sustav Zakonu o upravnim sporovima, kao i eventualno ostalim posebnim zakonima, a koji uređuju proces, odnosno postupak u upravnom sporu pred upravnim sudovima i Visokim upravnim sudom Republike Hrvatske.

Naime, potrebno je izgraditi sustav upravljanja sudskim dokumentima kao

17 Pravilnik o radu u sustavu eSpis, Narodne novine, br, 35/15.

18 Pravilnik o radu u sustavu eSpis, Narodne novine, br. 123/15., 45/16., 29/17., 112/17. i 119/18.

19 Prema statistici Ministarstva pravosuđa Republike Hrvatske, pristup https://pravosudje.gov.hr/ pravosudni-sustav-11207/sudovi/pokazatelji-ucinkovitosti/statistika-sudova/11211 
i omogućiti pretraživanje sadržaja sudskih odluka i podnesaka kroz sustav eSpis. Potrebno je i izgraditi sustav statističkih izvještavanja i analize statističkih izvještaja te omogućiti „skladištenje“ statističkih podataka, što bi sve doprinijelo učinkovitijem djelovanju upravnih sudova i Visokog upravnog suda Republike Hrvatske.

Potrebno je posebno prilagoditi algoritam za automatsku i nasumičnu dodjelu predmeta na upravnim sudovima i Visokom upravnom sudu Republike Hrvatske, kao i prilagoditi statističke podatke s novim Okvirnim mjerilima za rad sudaca, pritom uzevši u obzir osobitosti upravnog spora. ${ }^{20}$ Kao posebno se nameće pitanje elektroničkog potpisivanja sudskih odluka sukladno s certifikatima sudaca.

Svrha i cilj uvođenja sustava eSpis na upravne sudove svakako bi trebala biti ubrzanje rada sudova i kroz ažurno rješavanje predmeta i kroz bržu i efikasniju dostavu sudskih pismena, kao i rasterećenje sudaca nepotrebnim administriranjem u spisu, a što bi dovelo i do smanjenja troškova spora.

Međutim, u kontekstu učinkovitog djelovanja upravnih i sudskih tijela kao najbitnije smatramo omogućavanje povezivanja upravnog postupka i upravnog spora kroz sustav eSpis. Naime, osobitost upravnog spora posebno se očituje u činjenici kako se upravni spor pokreće nakon pravomoćno dovršenog upravnog postupka, uglavnom u dva stupnja te nakon što upravno tijelo provede dokaze kroz upravni postupak, bilo da pribavi određene isprave, sasluša svjedoke, provede očevid ili vještačenje.

Prema tome, upravnim sudovima kao i Visokom upravnom sudu Republike Hrvatske pri uvođenju sustava eSpis mora biti omogućeno da su upravni sudovi i Visoki upravni sud Republike Hrvatske povezani sa spisom upravnog postupka. Navedeno znači da elektronički spis u upravnom postupku u punom opsegu može migrirati u elektronički spis pred upravnim sudovima i Visokim upravnim sudom Republike Hrvatske, odnosno mora se omogućiti povezivanje elektroničkog spisa upravnog postupka s elektroničkim spisom u upravnom sporu. Navedeno povezivanje omogućiti ne samo prijenos svih podataka iz jednoga sustava u drugi, već i pohranu, odnosno „skladištenje“ tih podataka kao i njihovo pretraživanje i neograničeno korištenje.

Navedeno je propisano i odredbama Zakona o upravnim sporovima budući da se u članku 32. izrijekom propisuje kako sud tužbu sa svim prilozima dostavlja na odgovor tuženiku i zainteresiranim osobama, a da je tuženik uz odgovor na tužbu dužan priložiti, odnosno dostaviti sve spise koji se odnose na predmet spora. Pritom je nužno uzeti u obzir činjenicu kako je i zainteresirana osoba stranka u upravnom sporu (čl. 16. Zakona o upravnim sporovima) te je potrebno voditi računa da se navedeno povezivanje omogući što više i u odnosu na spise predmeta koje dostavlja u upravnom sporu zainteresirana osoba.

Posebno je važno da se sustav eSpis uskladi sa Zakonom u upravnim sporovima kao procesnim zakonom i drugim posebnim zakonima koji propisuju određena pravila postupanja za pojedino upravno područje kroz cijeli upravni spor, odnosno od podnošenja tužbe i do okončanja žalbenoga postupka, pri čemu se mora voditi računa

20 O problematici složenosti predmeta i vrstama sporova v. Boris Ljubanović, Upravno sudovanje u Republici Hrvatskoj - Quo Vadis?, u: Upravno sudovanje u Hrvatskoj: okrugli stol održan 29. lipnja 2017. u palači Akademije u Zagrebu, ur. Jakša Barbić (Zagreb: HAZU, 2017.), 137-146. 
i o postupku izvršenja sudskih odluka.

Predmetno znači da je ne samo potrebno omogućiti povezivanje upravnog postupka i upravnog spora kroz prijenos i pohranu podataka, odnosno spisa predmeta te kroz praćenje i analiziranje statističkih izvješća, već je potrebno omogućiti i „povezivanje“ upravnih sudova i Visokog upravnog suda Republike Hrvatske kao žalbenog suda, budući da u žalbenom postupku upravni sudovi dostavljaju spis sa svim prilozima, pa tako i sa spisima upravnog postupka Visokom upravnom sudu Republike Hrvatske radi razmatranja žalbe, odnosno donošenja odluke u svezi s izjavljenom žalbom.

Nužno je uzeti u obzir i pri provedbi sustava eSpis na upravne sudove i izvanredne pravne lijekove u upravnom sporu kao i eventualno „komunikaciju“ upravnih sudova i Visokog upravnog suda Republike Hrvatske s Državnim odvjetništvom Republike Hrvatske i Vrhovnim sudom Republike Hrvatske pri postupanju u svezi s podnesenim zahtjevom za izvanredno preispitivanje zakonitosti pravomoćne presude.

Ako se uzmu u obzir sve posebnosti upravnog spora te se pristupi uvođenju eSpisa na upravne sudove i Visoki upravni sud Republike Hrvatske, nesporno je da bi navedeno dovelo do daljnjega povećanja učinkovitosti rada navedenih sudova, budući da bi im se omogućila međusobna komunikacija elektroničkim putem, migracija pismena, kao i povezivanje s drugima sustavima, primjerice sustavom Ministarstva unutarnjih poslova, Financijskoj agencijom, Poreznom upravom i dr.

Elektronička bi komunikacija trebala omogućiti podnošenje podnesaka sudu elektroničkim putem, zaprimanje sudskih pismena u siguran elektronički poštanski pretinac, te uvid u sudske predmete putem interneta, odnosno portala sudova kao i kroz unaprijeđenu e-oglasnu ploču sudova. ${ }^{21}$

Nužno je omogućiti i elektroničku komunikaciju odvjetnika s upravnim sudovima i Visokim upravnim sudom Republike Hrvatske, budući da je na trgovačkim sudovima već u primjeni od 7. lipnja 2018., kao i omogućiti elektroničku komunikaciju između upravnih sudova i sudskih vještaka te sudskih tumača.

Isto tako smatramo da uvođenje sustava eSpis na upravne sudove i Visoki upravni sud Republike Hrvatske mora uključiti i suce tih sudova kao eventualno članove radnih skupina Ministarstva pravosuđa pri izradi plana implementacije eSpisa.

Pritom, smatramo da i u postupak provedbe trebaju biti uključeni i predstavnici Ministarstva uprave, jer je u ingerenciji ministarstva predlaganje izmjena i dopuna Zakona o općem upravnom postupku. Naime, uvođenje eSpisa na upravne sudove i Visoki upravni sud Republike Hrvatske, a u cilju što učinkovitijeg djelovanja upravnih i sudskih tijela, može biti ostvareno jedino povezivanjem elektroničkog spisa u upravnom postupku s elektroničkim spisom, koji će biti uveden na upravne sudove i Visoki upravni sud Republike Hrvatske.

Konkretno bi to značilo da se zajednički analiziraju specifičnosti upravnog postupka kao i radnje koje se provode tijekom njega te da se utvrđuje na koji bi način uopće dolazilo do prijenosa podataka (spisa predmeta) iz upravnog postupka u sudski

21 Više o tome: Frano Staničić i Marko Jurić, „Pravni okvir za implementaciju informacijskokomunikacijskih tehnologija u hrvatsko upravno postupovno pravo“", Zbornik Pravnog fakulteta Sveučilišta u Zagrebu 65, br. 5 (2015.): 635-663. 
spor. Također bi li bilo potrebno prenijeti sve spise predmeta iz upravnog postupka u upravni spor, ili bi se moglo točno odrediti koji bi se spisi predmeta iz upravnog postupka implementirali u upravni spor, pritom uzimajući u obzir osobitost svakog upravnog postupka, ali i u cijelosti zadovoljavajući navedenu odredbu čl. 32. Zakona o upravnim sporovima.

Pri prijenosu podataka, odnosno spisa nužno je uzeti u obzir i činjenicu predmeta upravnog spora, odnosno vodi li se upravni spor zbog ocjene zakonitosti pojedinačne odluke (upravni akt) ili eventualno ocjene zakonitosti postupanja te propuštanja javnopravnog tijela ili zbog ocjene zakonitosti sklapanja, izvršavanja i raskidanje upravnih ugovora. Mora se i omogućiti povezanost putem elektroničkog spisa između jedinica lokalne i područne (regionalne) samouprave te pravnih osoba koje imaju javnu ovlast i pravnih osoba koje obavljaju javnu službu s Visokim upravnim sudom Republike Hrvatske, cijeneći posebnost objektivnog upravnog spora, odnosno kada je predmet upravnog spora i ocjena zakonitosti općih akata.

\section{SUDAČKA NEOVISNOST I ESPIS}

Nezaobilazno je opće pravilo demokratskog društva sudačka neovisnost. Riječ je o pravilu koje određuje da suci sude samo prema svojem pravnom uvjerenju i vezani su samo na ustavna, zakonska i druga pravna pravila, a ne i za stajališta drugih tijela, posebno i tijela državne vlasti (tzv. suštinska ili supstancijalna sudačka neovisnost), zatim da moraju biti osigurani uvjeti kojima se postiže siguran i stalan osobni položaj (status) sudaca, kao i da se izuzmu od suđenja u konkretnom slučaju suci, kod kojih objektivni ili subjektivni razlozi izazivaju sumnju u nepristranost (tzv. osobna sudačka neovisnost).

Pravo na pošteno suđenje, zajamčeno čl. 6. EKLJP, uključuje više postupovnih prava među kojima je i „pravo da zakonom ustanovljeni neovisni i nepristrani... ispita... slučaj“.

Prema Ustavu Republike Hrvatske, odredba čl. 117., sudbena je vlast samostalna i neovisna i obavljaju je sudovi koji sude na temelju Ustava, zakona, međunarodnih ugovora i drugih važećih izvora prava.

Važeće hrvatsko pravo sadrži brojna pravila, ustavna i zakonska, kojima su ostvarene normativne pretpostavke za neovisnost sudova i sudaca. Među tim su pravilima za sudačku neovisnost vjerojatno najvažnija ona koja rješavaju pitanje postavljanja (odnosno imenovanja), razrješenja, premještaja i stegovne odgovornosti sudaca i predsjednika sudova. O svim tim pitanjima prema hrvatskom Ustavu, po uzoru na određene institucije u Italiji i Francuskoj, samostalno odlučuje, u skladu s Ustavom i zakonom, neovisno tijelo sudbene vlasti - Državno sudbeno vijeće. ${ }^{22}$

Važne zadaće Državnog sudbenog vijeća odnose se na Državnu školu za pravosudne dužnosnike kao ustrojstvene jedinice Pravosudne akademije (završetak te škole jedan je od zakonom propisanih uvjeta za imenovanje sudaca svih

22 To tijelo ima 11 članova, koji se biraju na vrijeme od četiri godine, a čine ga sedam sudaca (koje biraju sami suci), dva profesora pravnih znanosti (koje biraju profesori svih pravnih fakulteta) te dva saborska zastupnika, od kojih jedan iz redova oporbe (koje bira Hrvatski sabor). 
prvostupanjskih sudova od 1. siječnja 2013.). Vijeće provodi postupak upisa u školu, obavlja usmeni dio ispita kandidata za suce, obavlja razgovore s tim kandidatima te donosi odluku, o tzv. listi prvenstva kandidata za suce.

Važnu ulogu u postupku imenovanja sudaca i predsjednika sudova imaju posebna sudačka vijeća koja ne sude, već u postupku napredovanja sudaca, tj. promaknuća za suca višeg suda ocjenjuju rad sudaca u proteklom razdoblju tajnim glasovanjem, prema zakonom predviđenim mjerilima. U postupku imenovanja predsjednika sudova daju mišljenja o kandidatima koji su se prijavili na oglas o slobodnom mjestu predsjednika suda te ocjenjuju njihov sudački rad i programe rada. Vijeća o kojima je riječ, osnivaju se pri županijskim i drugim zakonom određenim sudovima, a biraju ih suci odnosnih sudova tajnim glasovanjem, iz reda sudaca.

Prema iznesenom, u kadrovskim pitanjima sudaca i predsjednika sudova, osim predsjednika Vrhovnog suda Republike Hrvatske, sudbena vlast, tj. Državno sudbeno vijeće kao neovisno tijelo sudbene vlasti i sudačka vijeća imaju visok stupanj autonomije. Iz nadležnosti sudbene vlasti izuzet je izbor i razrješenje predsjednika Vrhovnog suda Republike Hrvatske (na prijedlog predsjednika Republike bira ga i razrješava Hrvatski sabor, uz prethodno mišljenje opće sjednice Vrhovnog suda Republike Hrvatske i nadležnog odbora Hrvatskog sabora). Hrvatski sabor iz reda saborskih zastupnika bira i dva člana Državnog sudbenog vijeća, od kojih jedan mora biti iz redova oporbe. Nadležnost Ministarstva pravosuđa u kadrovskim pitanjima sudaca i predsjednika sudova svodi se na donošenje plana potrebnog broja sudaca, a ministra pravosuđa na davanje mišljenja o kandidatima za predsjednika suda, na podnošenje prijedloga za razrješenje predsjednika suda te na pokretanje stegovnog postupka protiv suca ili predsjednika suda zbog počinjenoga stegovnog djela.

I druge ustavne i zakonske odredbe relevantne su za ostvarivanje sudačke neovisnosti. Takve su osobito odredbe prema kojima je sudačka dužnost stalna, sudac se može razriješiti samo ako postoji razlog za razrješenje predviđen u Ustavu, premještaj suca protiv njegove volje moguć je samo kod ukidanja suda ili preustroja suda u skladu sa zakonom, poslovi se sucima i sudačkim vijećima raspodjeljuju prema rasporedu utvrđenom za svaku godinu, zabranjen je svaki oblik utjecaja na suce, sudac ne smije biti član političke stranke niti se baviti političkom djelatnošću, suci imaju imunitet te se plaće sudaca određuju zakonom.

Može se zaključiti da se pravna pravila koja pružaju, tzv. osobnu sudačku neovisnost dosljedno primjenjuju. Riječ je o pravilima kojima je uređeno imenovanje, razrješenje, premještaj i stegovna odgovornost sudaca, stalnost sudačke dužnosti, imunitet sudaca, plaće te izuzimanje suca od suđenja u konkretnom slučaju zbog sumnje u nepristranost.

Kad je o suštinskoj neovisnosti u praksi hrvatskoga pravosuđa riječ, nema podataka o vanjskom utjecaju, posebno izvršne vlasti na suca i sudove. Posljednjih su godina u žarištu interesa javnosti kazneni postupci zbog korupcijskih kaznenih djela protiv osoba iz samog vrha državne i političke vlasti. Sud ne može, suglasno akuzatornom (optužnom) načelu, započeti kazneni postupak na vlastitu inicijativu, nego samo na zahtjev ovlaštenog tužitelja, odnosno za veliku većinu kaznenih djela državnog odvjetništva (državnog ili javnog tužiteljstva). Kada je državno odvjetništvo 
u spomenutim i drugim slučajevima pokrenulo kaznene postupke i iznosilo dokaze dostatne za optužnicu, a potom i za osudu, sudovi su provodili kaznene postupke i donosili i donose osuđujuće presude neovisno o ranijem ili sadašnjem društvenom položaju optuženika. Suštinskoj sudačkoj neovisnosti u pravosudnoj praksi potpomaže pridržavanje propisa prema kojima karijerno napredovanje sudaca, tj. promaknuće za suca višeg suda ili predsjednika suda ne ovisi o volji aktualne izvršne ili zakonodavne vlasti, već se temelji ponajviše na ocjeni obnašanja sudačke dužnosti u proteklom razdoblju koju daju sami suci kao članovi za takve ocjene posebno formiranih sudačkih vijeća, u skladu sa zakonom ustanovljenim kriterijima. Među tim je kriterijima i broj odluka koje je sudac donio, pridržavanje rokova za donošenje i izradu odluka te kvaliteta odluke u povodu izjavljenih pravnih lijekova.

Sudačkoj neovisnosti u stvarnosti zasigurno pridonose i odluke Europskog suda u kojima se ponavlja da „tribunal“, odnosno sud mora biti neovisan o izvršnoj vlasti i strankama u postupku. U tim se odlukama navode i konkretni slučajevi povreda konvencijskog prava na neovisan i nepristran sud te utvrđuju konstitutivni elementi pojma „neovisan sud“.

Nužno je reći da propisani stroži zakonski uvjeti za imenovanje sudaca prvostupanjskih sudova mogu imati i negativne učinke za sudačku neovisnost i samostalnost. Važeći, tzv. „Zatvoreni model“ imenovanja sudaca prvog stupnja (završena Državna škola za pravosudne dužnosnike kao novi uvjet od 1. siječnja 2013.) praktički onemogućava postavljanje na položaj sudaca upravnih sudova upravne stručnjake s položenim pravosudnim ispitom. U Hrvatskoj je Zakonom o upravnim sporovima iz 2010., koji je stupio na snagu 1. siječnja 2012., uvedeno upravno sudovanje u dva stupnja (upravni sudovi u Osijeku, Rijeci, Splitu i Zagrebu te Visoki upravni sud u Zagrebu), s tim da su upravni sudovi dobili ovlast utvrđivati činjenice i provoditi usmene rasprave te, suglasno tomu, donositi tzv. reformacijske, a ne samo kasatorne odluke. Time se želi postići veća i potpunija zaštita prava i interesa stranaka u upravnom sporu te njihova veća pravna sigurnost. No, ti se ciljevi teško mogu dosegnuti, niti postići neovisnost i samostalnost sudaca upravnih sudova, ako o zakonitosti pojedinačnih odluka javnopravnih tijela (tijela državne uprave i drugih državna tijela, tijela jedinica lokalne $\mathrm{i}$ regionalne samouprave te pravnih osoba koje su nositelji javnih ovlasti), zakonitosti postupanja ili propuštanja postupanja javnopravnih tijela te o zakonitosti upravnih ugovora odlučuju suci koji, doduše, imaju završenu Državnu školu za pravosudne dužnosnike, ali su bez potrebnih znanja $\mathrm{i}$ iskustava u rješavanju upravnih predmeta.

U sklopu reforme i informatizacije pravosuđa Republika je Hrvatska uvela eSpis 2007. Sustav eSpis možemo definirati kao informatički sustav za bilježenje i praćenje podataka vezanih za sudske predmete. To je jedinstveni sustav za sve tipove predmeta na općinskim, županijskim, trgovačkim sudovima te na Vrhovnom sudu Republike Hrvatske. Nedvojbeno je da njegovo uvođenje doprinosi transparentnosti sudskih postupaka, omogućava pravo na pristup informacijama, standardizira sudsko poslovanje, omogućava dostupnost relevantnih podataka u realnom vremenu, ali možemo slobodno reći, doprinosi i sudskoj neovisnosti u svakom smislu.

Sukladno svemu navedenom, nesporno je da bi uvođenje eSpisa na upravne 
sudove i Visoki upravni sud Republike Hrvatske, ako se ispune navedene pretpostavke, dovelo do povećanja učinkovitosti upravnih sudova i Visokog upravnog suda Republike Hrvatske, a time i do povećanja učinkovitosti rada upravnih tijela. Međutim, preduvjet za ostvarivanje svrhe i cilja uvođenja sustava eSpisa u upravne sudove i Visoki upravni sud Republike Hrvatske svakako je povezivanje upravnog postupka i upravnog spora, odnosno omogućavanje povezivanja elektroničkog spisa upravnog postupka i elektroničkog spisa upravnog spora.

Predmetno bi povezivanje značilo u cijelosti prilagodbu elektroničkog spisa procesnim odredbama odnosno odredbama Zakona o općem upravnom postupku i Zakona o upravnim sporovima. Pritom bi bilo potrebno i izmijeniti navedeni Pravilnik o radu u sustavu eSpis, budući da on ne uređuje postupanje upravnih sudova i Visokog upravnog suda Republike Hrvatske u sustavu eSpis, jer je provedba sustava za upravni spor (upravni sudovi i Visoki upravni sud Republike Hrvatske) predviđena u 2020. godini.

Kod ocjene zakonitosti provedenog upravnog postupka kao i donesenih odluka nakon provedenog upravnog postupka, kao i kod ocjene je li upravno tijelo postupalo sukladno s načelima ekonomičnosti i učinkovitosti, upravnim sudovima i Visokom upravnom sudu Republike Hrvatske mora biti omogućen uvid i pregled svih podataka iz elektroničkog spisa upravnog postupka kao i eventualni prijenos pojedinih spisa (dokaza) iz upravnog postupka, a koji spis ili dokazi eventualno nisu u elektroničkom spisu upravnog postupka, odnosno bila bi riječ o spisima predmeta upravnog postupka $\mathrm{u}$ isključivo papirnatom obliku.

Nužno je utvrditi hoće li eSpis pri uvođenju na upravne sudove i Visoki upravni sud Republike Hrvatske biti u cijelosti elektronički spis ili će navedeni sudovi u određenom dijelu još uvijek imati ,papirnati“ spis. Ako bi se u cijelosti uveo elektronički spis na sudove, nužno je razmotriti i uvođenje digitalne arhive, odnosno bilo bi potrebno uspostaviti elektroničku arhivu, kao i podršku za obradu skeniranih dokumenata.

\section{ZAKLJUČAK}

Nesporno je da elektronički spis (eSpis) dovodi do učinkovitijeg djelovanja upravnih i sudskih tijela, budući da omogućava brže „kolanje“ podatka, bržu statističku pohranu i analizu podataka, povezanost $\mathrm{s}$ drugim informatičkim sustavima raznih upravnih tijela, praćenje upravnog i sudskog spisa putem javnih portala, odnosno mrežnih portala i e-oglasne ploče sudova (e-komunikacija).

Isto tako, elektronički spis pri implementaciji svih podataka i njihovoj analizi omogućava i bolje te brže „upravljanje“ spisom što povećava i učinkovitost. Uz omogućavanje već navedenih funkcionalnosti, nesporno bi omogućavao i službenoj osobi u upravnom postupku, kao i sucima upravnih sudova i Visokog upravnog suda Republike Hrvatske, korištenje vrlo kvalitetnih upravljačkih alata, odnosno upravljačkih izvješća, a što bi doprinijelo i (doprinosi) boljem i bržem radu upravnih i sudskih tijela odnosno učinkovitom djelovanju upravnih i sudskih tijela.

Ovaj zaključni tekst dovršavamo konstatacijom da za zbiljsku neovisnost 
sudova i sudaca nije dostatan samo normativni aspekt neovisnosti. Jer, kako je govorio akademik Siniša Triva: „Čovjek i njegov etički habitas, determiniran ne samo opredjeljenjem moćnika koji treba da odluči već, nadasve, genetskim naslagama nataloženim kroz generacije i njegovoj svjesnoj i podsvjesnoj osobnosti, i ovdje igraju odlučnu ulogu“. ${ }^{23}$

\section{LITERATURA}

Knjige i članci:

1. Dika, Mihajlo. „O razvitku instituta sudske (sudačke) nezavisnosti u zapadnoeuropskom civilizacijskom krugu“. Zbornik Pravnog fakulteta u Zagrebu suppl. br. 4 (1992.): 511533.

2. Đerđa, Dario i Marko Šikić. Komentar Zakona o upravnim sporovima. Zagreb: Novi informator, 2010.

3. Krapac, Davor. Kazneno procesno pravo. Prva knjiga: Institucije. Zagreb: Narodne novine, 2012.

4. Ljubanović, Boris. Upravno sudovanje u Republici Hrvatskoj - Quo Vadis?, Hrvatska akademija znanosti i umjetnosti. U: Upravno sudovanje u Hrvatskoj: okrugli stol održan 29. lipnja 2017. u palači Akademije u Zagrebu, ur. Jakša Barbić. Zagreb: HAZU, 2017.

5. Ministarstvo pravosuđa Republike Hrvatske, pristup 30. studenoga 2019. https:// pravosudje.gov.hr/pravosudni-sustav-11207/sudovi/pokazatelji-ucinkovitosti/statistikasudova/11211

6. Picardi, Nicola. Rapport General sur l'independance et la Responsabilite des Juges et des Avocats; Congres de l'Association Internationale du Droit Procedural, Comibra - Lisbon 1991 (General Reports).

7. Potočnjak, Željko. „Pravo na sud, pristup sudu i suđenje u razumnom roku u slučaju intervencije zakonodavca u sudske postupke u tijeku“, Zbornik Pravnog fakulteta Sveučilišta u Rijeci br. 2 (2004.): 823-853.

8. Shetreet, Shimon. Judges on Trial: A Study of the Appointment and Accountability of the English Judiciari. Amsterdam: North-Holland Pub., 1976.

9. Staničić, Frane i Marko Jurić. „Pravni okvir za implementaciju informacijskokomunikacijskih tehnologija u hrvatsko upravno postupovno pravo“. Zbornik Pravnog fakulteta Sveučilišta u Zagrebu 65, br. 5 (2015.): 635-663.

10. Staničić, Frane, Bosiljka Britvić Vetma i Božidar Horvat. Komentar Zakona o upravnim sporovima, Zagreb: Narodne novine, 2017.

11. Šikić, Marko. Pravo na suđenje u razumnom roku u postupcima pred Upravnim sudom Republike Hrvatske“. Zbornik Pravnog fakulteta Sveučilišta u Rijeci 30, br. 1 (2009.): 333-372.

12. Triva, Siniša. „Vrhovno sudbeno vijeće - Consiglio superiore della magistratura“. Zbornik Pravnog fakulteta u Zagrebu suppl. br. 4 (1992.): 561-573.

Hrvatski pravni propisi:

1. Pravilnik o radu u sustavu eSpis, Narodne novine, br, 35/15., 123/15., 45/16., 29/17., 112/17. i 119/18.

2. Zakon o općem upravnom postupku, Narodne novine, br. 47/09.

3. Zakon o sudovima, Narodne novine, br. 28/13., 33/15., 82/15., 82/16., 67/18., 126/19.

23 Siniša Triva, „Talijansko Vrhovno sudbeno vijeće - Consiglio superiore della magistratura“, Zbornik Pravnog fakulteta u Zagrebu suppl. br. 4 (1992.): 572. 
Sudska praksa:

1. Cvijetić protiv Hrvatske, presuda ESLJP od 26. veljače 2004., br. 71549/01

2. Lukavica protiv Hrvatske, presuda ESLJP od 5. srpnja 2007., br. 39810/04

3. Mikulić protiv Hrvatske, presuda ESLJP od 20. prosinca 2001., br. 52634/99

4. Pobernik protiv Hrvatske, presuda ESLJP od 4. ožujka 2004., br. 75139/01

5. Počuča protiv Hrvatske, presuda ESLJP od 29. lipnja 2006., br. 22457/02

6. Ustavni sud RH U-IIIVs-664/2007 od 11. ožujka 2009.

7. Ustavni sud RH U-III-2937/2001 od 14. prosinca 2011.

8. Ustavni sud RH U-IIIA-4882/2007 od 20. lipnja 2006.

9. Ustavni sud RH U-IIIs-4242/2007 od 20. travnja 2009.

10. Ustavni sud RH U-III-2009 od 3. studenoga 2001. 
Prof. dr. sc. Boris Ljubanović*

Izv. prof. dr. sc. Bosiljka Britvić Vetma**

Summary

\section{E-FILES SYSTEM (eSPIS) AS A MEAN OF EFFECTIVE OPERATION OF THE ADMINISTRATIVE AUTHORITIES AND COURTS}

The authors write on the need for effective action by administrative and judicial bodies, with particular reference to judicial independence in the resolution of cases and to trial within a reasonable time. They analyze the eSpis system and its effect on faster and more efficient case resolution.

Keywords: administrative bodies; judicial bodies; judicial independence; reasonable time; e-files system (eSpis).

Zusammenfassung

\section{ELEKTRONISCHE AKTENVERWALTUNG (eSPIS) ALS WIRKUNGSVOLLES HANDELN DER VERWALTUNGSBEHÖRDEN UND GERICHTE}

Die Autoren erörtern das Bedürfnis an wirkungsvolles Handeln von Verwaltungsbehörden und Gerichten mit besonderer Berücksichtigung der richterlichen Unabhängigkeit bei der Entscheidung über Fälle und des Verfahrens innerhalb vernünftiger Zeit. Sie analysieren die elektronische Aktenverwaltung (eSpis) und ihr Einfluss auf schnellere und wirkungsvollere Entscheidung über Fälle.

Schlüsselwörter: Verwaltungsbehörden; Gerichte; richterliche Unabhängigkeit; elektronische Aktenverwaltung (eSpis).

* Boris Ljubanović, Ph.D., Full Professor, Josip Juraj Strossmayer University of Osijek, Faculty of Law; ljboris@pravos.hr.

** Bosiljka Britvić Vetma, Ph.D., Associate Professor, University of Split, Faculty of Law; bosiljka.britvic@pravst.hr. 
Riassunto

\section{IL SISTEMO DI FASCICOLO ELETTRONICO (eSPIS) IN FUNZIONE DI UN EFFICACE FUNZIONAMENTO DELL'APPARATO AMMINISTRATIVO E GIUDIZIARIO}

Gli autori rilevano la necessità di una resa più efficace dell'apparato amministrativo e giudiziario, prestando particolare attenzione all'esigenza di autonomia dei giudici nella risoluzione delle controversie e della conduzione dei processi entro tempi ragionevoli. Analizzano il sistema dei fascicoli elettronici (eSpis) e l'effetto che questo ha su una risoluzione più rapida ed efficace delle pratiche.

Parole chiave: apparato amministrativo; apparato giudiziario; autonomia della giustizia; durata ragionevole; fascicolo elettronico (eSpis). 